\title{
Chromosomal Abnormalities in Mentally Retarded Boys Other than Down's Syndrome in Indonesian Special Schools
}

\author{
M.H. Sultana ${ }^{\star}$, P.R.L. Lam-Po-Tang ${ }^{\dagger}$, Hariyono Suyitno ${ }^{\ddagger}$, Ag. Soemantri ${ }^{\ddagger}$
}

\begin{abstract}
Abstrak
Kelainan kromosom merupakan suatu petunjuk penyebab retardasi mental. Kelainan genetik pada retardasi mental tersering adalah trisomi-21 (sindrom Down), kemudian diikuti oleh sindrom "fragile-X". Sindrom "fragile X" merupakan penyakit retardasi mental yang dapat diwariskan dari generasi ke generasi berikutnya. Gangguan kromosom pada anak-anak retardasi mental belum pernah diteliti di Indonesia. Makalah ini melaporkan penelitian pada anak yang menderita retardasi mental, murid dari 6 sekolah luar biasa untuk retardasi mental ringan (SLB-C) di Semarang dan dua kota kabupaten di Jawa Tengah (Cilacap dan Purbalingga). Dari 6 SLB-C telah diamati secara klinik 460 murid/subyek. Pemeriksaan sitogenetika dikerjakan pada 164 siswa laki-laki subyek. Dari 340 subyek di Semarang didapatkan secara klinik 42 anak (12,3\%) dengan sindrom Down, sedangkan di Purbalingga dan Cilacap didapatkan sindrom Down masing-masing 5 anak $(8,7 \%)$ dari 57 murid dan 8 anak $(12,6 \%)$ dari 63 murid. Pemeriksaan sitogenetika pada subjek di Semarang, mengidentifikasi 4 anak dengan sindrom "fragile- $X^{\prime \prime}(3,1 \%)$ dan 7 anak $(5,46 \%)$ dengan bentuk aneuploidi lainnya. Penemuan sitogenetika "fragile- $X$ " positif telah dikonfirmasi dengan pemeriksaan DNA. Pemeriksaan sitogenetika pada sampel yang berasal dari 2 kota lainnya hanya mendapatkan satu kasus kelainan kromosom.
\end{abstract}

\begin{abstract}
Chromosomal abnormalities is a leading cause of mental retardation. The most common genetic cause of mental retardation is trisomy 21, followed by fragile-X syndrome which is inherited i.e passed on from generation to generation. Chromosomal disorders in mentally retarded children have not been studied in Indonesia. This paper reports a survey of chromosomal abnormalities in mentally retarded children attending special schools for mild mental retardation (t)pe C) in Semarang and two towns in Central Java, Indonesia (Cilacap and Purbalingga). A total of 460 pupils as subject (from 6 schools) were clinically screened. A cytogenetic study was made on 164 mentally retarded boys without Down's syndrome facies. Of the 340 subjects in Semarang, 42 (I2.3\%) had Down's syndrome clinically. In the rural area we identified $5(8.7 \%)$ Down's syndrome out of 57 pupils in Purbalingga and $8(12.6 \%)$ out of 63 pupils in Cilacap. Cytogenetic study in Semarang identified four (3.1\%) fragile-X syndrome and seven (5.46\%) other aneuploid constitutions. The positive fragile-X cytogenetic findings were confirmed with DNA study. Cytogenetic study in the samples from rural area only identified one case of chromosomal abnormality.
\end{abstract}

Keywords : Mental retardation, Central Java, Semarang, Purbalingga, Cilacap, Down's Syndrome, Fragile-X

The cause of childhood mental retardation could be obstetric problems at birth, prematurity, perinatal trauma, infections/intoxications, metabolic disorders, chromosome abnormalities (genetic disorders) and psychiatric disorders. Trisomy-21 (Down's syndrome) as a chromosomal abnormality is the most common

\footnotetext{
"Department of Histology, Faculty of Medicine, Diponegoro University, Semarang/Cytogenetics Unit Telogorejo Hospital, Semarang, Indonesia.

${ }^{\dagger}$ Department of Haematology/Cytogenetics and Cell Biology Unit Prince of Wales Hospital, Randwick, Sydney; NSW 2031, Australia.

${ }^{\ddagger}$ Department of Pediatrics, Faculty of Medicine, Diponegoro University, Semarang, Indonesia
}

genetic cause of mental retardation. Fragile $\mathrm{X}$ syndrome is the second genetic cause and the frequent known inherited cause of mental retardation. Mentally retarded children are usually educated in special schools.

In Central Java province most children with mental retardation attend special schools for the intellectually handicapped. In Semarang city (the capital of Central Java province) there are four such special schools and in every kabupaten (regency) there is at least one such school. There are three classifications of special schools i.e. type $\mathrm{C}$ for educable children (IQ 50-70/ imbecile), type $\mathrm{C} 1$ for trainable children (IQ 25$50 /$ debile/moron) and type $\mathrm{C} 2$ for untrainable children (IQ $<25 /$ idiot). 
Chromosomal disorders in mentally retarded children have not been studied in Indonesia. This paper reports a survey of chromosomal abnormalities in mentally retarded boys other than Down syndrome attending special schools for mild mental retardation (type C) in Semarang (4 schools) and two towns (rural area) in Central Java, Indonesia.

\section{METHODS}

\section{Selection of children in special schools for mental retardation}

During March-November 1994, 340 pupils (187 males, 153 females) from 4 special schools (type C) for the mentally retarded in Semarang were surveyed (Table 1). In June 1995 there was a further survey in two special schools in two rural areas: Purbalingga 57 pupils (41 males, 16 females) and Cilacap 63 pupils (32 males, 31 females) (Table 1). Their ages varied between 6 to 24 years (school age), mostly of them between 6 to 15 years. These pupils had been admitted to the school after medico-psychological evaluation and IQ testing. Only those with an IQ score of above 50 (mild mental retardation) were admitted to $C$ type classes.

\section{Clinical examination}

Limited physical examination of all subjects (males and females) was undertaken by assessing their facies and obvious deformities and were classified as Down's syndrome, suspected Down's syndrome and normal or with minimal dysmorphism. When an abnormal clinical finding was found, a further examination was undertaken including measurement of testicular size (comparative palpation) using testicular models of known volume (orchidometer). ${ }^{1}$

\section{Blood collection}

Ten $\mathrm{ml}$ of heparinized peripheral blood were drawn from boys without classical Down's syndrome facies, for cytogenetic and DNA analysis. Blood samples were also drawn from female siblings as well as from the parents of the boys, who has chromosomal abnormalities and familial mental retardation, for family studies. Blood samples were obtained from 128 boys (Semarang), 19 boys (Purbalingga), 17 boys (Cilacap) without the clinical features of Down's syndrome or obvious congenital abnormalities. Boys with suspected Down's syndrome who have minimal stigmata were included in the study.

\section{Cytogenetic studies}

Lymphocyte culture and metaphase preparations were performed according to standard methods using folate free media in order to detect fragile-X. Fifty unbanded cells were microscopically scanned. If a fragile site in the $C$ group were found, a further 50 cells were scanned and the slides were destained and banded to confirm the fragile-X. Six further fresh banded cells were analyzed and another 14 cells were counted to assess other chromosomal abnormalities.

Table 1. Clinical sufvey in special schools for the mentally retarded in Semarang city, Purbalingga and Cilacap

\begin{tabular}{|c|c|c|c|c|c|c|}
\hline \multirow[t]{2}{*}{ Location } & \multicolumn{2}{|c|}{ Sex } & \multicolumn{4}{|c|}{ Clinical Examination (Males/Females) } \\
\hline & Males & Females & $\begin{array}{l}\text { Down's } \\
\text { syndrome }\end{array}$ & $\begin{array}{l}\text { Suspected } \\
\text { Down's syndr }\end{array}$ & $\begin{array}{c}\text { Minimal } \\
\text { abnormalitjes* }\end{array}$ & Total \\
\hline \multirow{4}{*}{ Semarang } & 43 & 50 & 6 & 1 & 86 & 93 \\
\hline & 29 & 20 & 5 & - & 44 & 49 \\
\hline & 89 & 67 & 24 & 3 & 129 & 156 \\
\hline & 26 & 16 & 7 & 1 & 34 & 42 \\
\hline $\begin{array}{l}\text { Total } \\
\text { (Semarang) }\end{array}$ & 187 & 153 & 42 & 5 & 293 & 340 \\
\hline Purbalingga & 41 & 16 & 5 & - & 52 & 57 \\
\hline Cilacap & 32 & 31 & 8 & - & 55 & 63 \\
\hline Total & 260 & 200 & 55 & 5 & 400 & 460 \\
\hline
\end{tabular}

* Minimal abnormalities: children showing minimal abnormalities of indefinite syndrome or unknown syndrome 


\section{Molecular studies}

Southern blotting of Pst1 digested genomic DNA (restriction fragment length polymorphism/RFLP) was performed. Using the FRAXA probe (pfxa3) and an $\mathrm{X}$-chromosome single locus control probe (pS8), (both kindly supplied by Professor G. Sutherland, Adelaide), the cytogenetically positive fragile- $X$ cases were confirmed.

\section{RESULTS}

A total of 128 males from Semarang were studied cytogenetically and the results are summarized in Table 2. There were 11 children with chromosomal abnormalities, four were positive fragile- $X$ (with the following number of positive cells, $3 \%$ in $\mathrm{Dm}, 4 \%$ in $\mathrm{Pr}, 3 \%$ in Iw and $1 \%$ in $\mathrm{Zn}$ ) and seven with abnormal karyotypes namely two $47, \mathrm{XY}+21,46, \mathrm{XY},-7,+$ der (7) $\mathrm{t}(7 ; ?)(\mathrm{p} 22 ; ?), \quad 46, X Y, d u p(9)(\mathrm{p} 13->\mathrm{p} 24)$, $48, \mathrm{XXXY}, 46, \mathrm{XY} / 46 \mathrm{XY}, \mathrm{r}(22)$ and $46, \mathrm{XY},+$ mar 15 (confirmed by fluorescence in situ hybridization studies). The two $47, \mathrm{XY}+21$ were found from the five cases with suspected Down's syndrome. Both cases had minimal stigmata of Down's syndrome such as a big tongue and upslanting eyes in one case and hypertelorism and stubby hand in the other case. The four fragile-X positive cases were found in two families. DNA analysis by Southern blotting showed a mosaicism pattern $1.6 \mathrm{~kb}$ and $2.6 \mathrm{~kb}$ band in $\mathrm{Dm}, 2.2$ $\mathrm{kb}$ band in $\mathrm{Pr}$ from family 1 , and $2.1 \mathrm{~kb}$ band in Iw from family 2 , which confirmed the affected fragile-X children to have full mutation and $1.3 \mathrm{~kb}$ band in $\mathrm{Zn}$ from family 2 , which confirmed the affected fragile- $X$ child to have premutation. There was only one chromosomal abnormality in the samples from rural area (Cilacap), namely 46,XY/47,XYY (see Table 3 ). Only half of the boys from the two rural schools were included in the study since they were absent during the post exam and four boys refused to have blood collection (two from each school). In Semarang special schools there were difficulties in seeing those children as they were scared and rejected. There were 22 boys rejected i.e. eight from Y school, five from DB school, five from W school and four from P school.

Table 2. Cytogenetic study in boys without classical Down's syndrome in Semarang city

\begin{tabular}{lcccc}
\hline \multirow{2}{*}{$\begin{array}{l}\text { Special Schools } \\
\text { in Semarang }\end{array}$} & \multicolumn{4}{c}{ Cytogenetics findings } \\
\cline { 2 - 5 } & Fragile X positive & Others & $46, X Y$ & Total \\
\hline Y & 2 & 1 & 31 & 34 \\
DB & 2 & - & 18 & 20 \\
W & - & 4 & 55 & 59 \\
P & - & 2 & 13 & 15 \\
\hline Total & 4 & 7 & 117 & 128 \\
\hline
\end{tabular}

Table 3. Cytogenetic study in boys without classical Down's syndrome in Purbalingga and Cilacap

\begin{tabular}{lcccc}
\hline & \multicolumn{3}{c}{ Cytogenetic findings } \\
\cline { 2 - 5 } Location & Fragile X positive & Others & $46, \mathrm{XY}$ & Total \\
\hline Purbalingga & - & - & 19 & 19 \\
Cilacap & - & 1 & 16 & 17 \\
\hline Total & - & 1 & 35 & 36 \\
\hline
\end{tabular}




\section{DISCUSSIONS}

In our survey we found $30 \%$ excess of males over females (260/200) in mentally retarded institutions (Table 1). This male preponderance is similar to that found in other surveys of mentally retarded persons where there was an excess of $20 \%$ which was ascribed to X-linked mental retardation (XLMR). ${ }^{2}$ The incidence of Down's syndrome with typical clinical features was $12.3 \%$ of the population in Semarang schools and $11 \%$ of the population in rural area schools, which was lower when compared with other previous studies i.e. $18 \%$ in Taiwan $(1988)^{3}$ and $15 \%$ in most Caucasian studies. ${ }^{4}$ There were $3.1 \%$ fragile-X syndrome and $5.46 \%$ other chromosomal abnormalities in Semarang mentally retarded school boys, compared to the $3.8 \%$ both fragile- $\mathrm{X}$ and other chromosomal abnormalities seen in Taiwan study. ${ }^{3}$ Comparison with other Asian fragile-X screening study (Japan) showed $10 \%$ Down's syndrome and 5.3\% Fragile-X syndrome in institutionalized mentally retarded males. ${ }^{5}$ About $40 \%$ of XLMR and $4 \%$ of all mental retardation has been attributed to fragile- $X$ syndrome. ${ }^{6,7}$ Institutionalized populations studies in different countries such as Germany (1983), Finland (1983), UK (1986), USA (1984) showed that the incidence of fragile- $X$ syndrome among males were $6.2 \%, 4 \%, 7.9 \%, 4.1 \%$ respectively. ${ }^{8} \mathrm{~A}$ study of mentally retarded population in Australia (Sutherland 1985) found 3.35\% fragile-X syndrome in mentally retarded boys ${ }^{9}$ which was very similar with our study in Semarang. Cytogenetic screening studies for the male individuals attending adult and child facilities for intellectually handicapped in New South Wales found positive fragile-X $6.5 \%$, $10.6 \%$ and $18.6 \%$ in the programme $1984-1985,1986-$ 1988 and $1989-1990$ respectively. ${ }^{10}$ Overall studies in New South Wales found an additional $2 \%$ with other chromosome anomalies of those tested for fragile- $\mathrm{X}$ and $10 \%$ chromosome anomalies out of suspected chromosome disorders. The Autralian, European and American figures showed a higher prevalence of fragile- $X$ than Asian figure found in the literature and in our study, but this trend cannot be analyzed statistically.

Our study in the rural areas identified only one chromosomal abnormality without any fragile- $\mathrm{X}$ case. The sampling was incomplete because the number of children studied in rural areas were too small to provide useful analysis. Most of the children in rural area special schools have been stayed in school dormitory, their parents tend to pick them up and allow them to stay home in post exam (end of academic year). The lower incidence in Indonesia could be due to cultural factors that allow children to stay at home and caused an incomplete sampling. The boys from six mentally retarded school surveyed were not all included in this study since some of them refused to have blood collection. Some mentally retarded children and adult was not covered in this study since they did not attend special school or sheltered workshop for economic reasons.

The frequency of positive fragile-X cells $(1-4 \%)$ in fragile-X patients appears to be lower than in other studies $(2-50 \%)^{6,8}$ It is possible that although low folate medium was used, there was enough folate in foetal bovine serum (FBS) of the medium to reduce the incidence of fragile-X expression. The size of the trinucleotide repeat expansion (CGG repeat) is a causal factor in the expression of fragile site. ${ }^{11}$ The four fragile-X positive cases were found in two families. Southern blotting showed a mosaicism pattern i.e. 1.6 $\mathrm{kb}$ and $2.6 \mathrm{~kb}$ band in $\mathrm{Dm}, 2.2 \mathrm{~kb}$ band in Pr from family 1 and $2.1 \mathrm{~kb}$ band in Iw from family 2 , which confirmed the affected fragile- $\mathrm{X}$ children to have full mutation. Those full mutation cases showed typical fragile-X syndrome such as high forehead, prominent jaw, long ears and shyness (reported in previous paper). ${ }^{12}$ One positive fragile- $\mathrm{X}$ case $(\mathrm{Zn})$ found as premutation with $1.3 \mathrm{~kb}$ band ( $\sim 90$ CGG repeats) showed only $1 \%$ fragile-X positive cells cytogenetically. In general, males with premutation i.e. the size of trinucleotide repeat $60-200$ repeat $(<1.6 \mathrm{~kb}$ band) almost do not show phenotypic abnormalities and called as normal transmiting males (NTM). ${ }^{13,14}$ Our case with the $1.3 \mathrm{~kb}$ band showed normal looking but he was mentally retarded. It was presumably caused by methylation in $\mathrm{CpG}$ island of FMR-1 gene. ${ }^{15}$ DNA analysis by using Southern blotting of Pst 1 product of fragile- $\mathrm{X}$ cases showed bands of more than $1.6 \mathrm{~kb}$ in affected individual (full mutation). This pattern was the same as in Caucasian cases. ${ }^{16}$

\section{Acknowledgment}

This work was supported by the Six Universities Development and Rehabilitation Project of the Department of Education and Culture, ADB loan no. 1013INO. We wish to thank the parents, the heads and staff of the special schools for providing records and clinical data, allowing us to examine the children and collect the blood samples. Particular thanks are extended to the laboratory staff of Telogorejo Hospital Semarang for their assistance in the collection of samples and preliminary preparation of samples, and to the laboratory staff of the Prince of Wales Hospital, Sydney for their assistance and advice. 


\section{REFERENCES}

1. Prader A. Testicular size: Assesment and clinical importance. Triangle 1966;7:240-3.

2. Turner G, Turner B. X-linked mental retardation. Am J Med Gen 1974;11:109-13.

3. Li SY, Tsai CC, Chou MY, Lin JK. A cytogenetic study of mentally retarded school children in Taiwan with special reference to the fragile $\mathrm{X}$ chromosome. Hum Genet 1988:79:292-6.

4. Gorlin RJ, Cohen MM, Levin LS. Syndrome of the head and neck. 3rd ed. Oxford: Oxford University Press, 1990.

5. Arinami T, Kondo I, Nakajima S. Frequency of the fragile $\mathrm{X}$ syndrome in Japanese mentally retarded males. Hum Genet 1986;73:309-12.

6. Connor JM, Ferguson-Smith MA. Essential Medical Genetics. 4th ed. Oxford: Blackwell Scientific Publications, 1993.

7. Mikkelsen M. Sex-linked mental retardation. In: Vogel F, Sperling K, editors. Human Genetics. Berlin: Springer-Verlag, 1987;441-9.

8. Davies KE, editor. The Fragile X syndrome. Oxford: Oxford University Press, 1989.

9. Sutherland GR. Heritable fragile sites on human chromosomes XII. Population Cytogenetics. Annals of Hum Gen 1985;49:153-61.
10. Turner G, Robinson H, Laing S, Van den Berk M, Colley A, Goddard $\mathrm{A}$ et al. Population Screening for fragile $\mathrm{X}$. The Lancet 1992;339:1210-3.

11. De Vries BBA, Wiegers AM, De Graaff E, et al. Mental status and fragile $X$ expression in relation to FMR-1 gene mutation. Eur J Hum Genet 1993;1:72-9.

12. Sultana, Soemantri Ag, Lam-Po-Tang PRL, Wright F, Lindeman R, Purvis-Smith S. Fragile-X mental retardation in an Indonesian family. Med J Indones 1995;4:17-23.

13. Rousseau F, Heitz D, Tarleton J, Biancalana V, Blumenfeld $\mathrm{S}$, Kretz $\mathrm{C}$ et al. Direct diagnosis by DNA analysis on the fragile $\mathrm{X}$ syndrome of mental retardation. $\mathrm{N}$ Engl J Med 1991;325,1673-81.

14. Oberle I, Rousseau F, Heitz D, Kretz C, Devys D, Hanauer $A$, et al. Instability of a 550-base pair DNA segment and abnormal methylation in fragile $\mathrm{X}$ syndrome. Science 1991;252:1097-102.

15. Smeets HJM, Smits APT, Verheij CE, Theelan JPG, Willemsen R, Van den Burgt I, et al. Normal phenotype in two brothers with a full FMR-1 mutation. Hum Mol Genet 1995;4:2103-8.

16. Sutherland GR, Gedeon A, Kornman L, Donnelly A, Byard RW, Mulley JC, et al. Prenatal diagnosis of fragile X syndrome by direct detection of the unstable DNA sequence. New England J Med 1991;325:1720-2. 